\title{
URBAN GREENWAYS AS PLANNING STRATEGY
}

\author{
Krishnanjana K \\ Department of Architecture \\ Govt. Engineering College, Thrissur, Kerala, India
}

\begin{abstract}
Cities across the world have developed urban greenways as a tool to tackle the problems caused by rapid and unsustainable urbanisation. In many of the countries greenways are used to achieve a number of environmental, economic, and social goals. Greenways are recreational trails that provide functions beyond recreation, such as storm water management, economic development, community development, and aesthetic improvements. However, greenways are not a new idea. The popularity of greenways has grown because greenways fulfil many functions, while bringing numerous benefits to the cities in which they are implemented.
\end{abstract}

\section{Keywords-Greenways, Recreational trails}

\section{INTRODUCTION}

Urban areas are great magnets to most humans. Indeed, around 2.8 billion people worldwide live in urban areas. Urban areas are the nucleus of economic growth, the major sources of new technology and wealth. However, they also face significant problems: uneven urban development, creation of economic and social 'sink' areas, and environmental decay (urban areas are the major consumers of natural resources and the largest producers of pollution and waste). The massive increase in urbanization and the impact of urban areas on the global environment mean that creating more sustainable urban areas is essential to sustainability at the national and international level.

The rest of the paper is organized as follows. Concept of Greenways and its advantages are explained in section II. Case studies along with analysis are presented in section III. Concluding with recommendations for planning Greenways are given in section IV.

\section{CONCEPT OF GREENWAYS}

\section{A. Characterestics and functions -}

When planned and executed in the right way, urban greenways tie together the environmental, economic, and social equity goals of sustainable development and lead to improved urban resilience Changing of conditions, conceptions and tendencies lead to change of the concept and scope of greenways. There are five key characteristics for this Greenways - Linear,
Linkage, Multifunctional, Consistent and Spatial strategy component of the original image detail (high frequency).

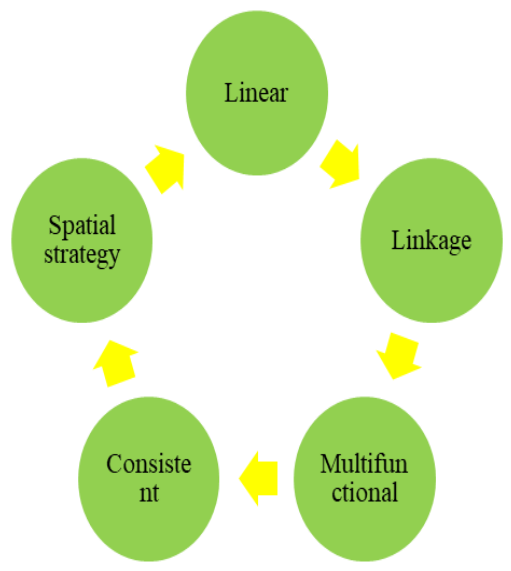

Fig. 1. 5 key characterestics

\section{B. Benefits of Greenways -}

Greenways provide many benefits that increase quality of public life with using spaces for multiple goals. Benefits of greenways can be broadly classified in to 3 categories Environmental benefits, Economic benefits and social benefits.

\begin{tabular}{|l|l|l|}
\hline \multicolumn{3}{|c|}{ Table -1 Benefits of Greenways } \\
Environmental & $\begin{array}{l}\text { Economic } \\
\text { benefits }\end{array}$ & Social benefits \\
\hline $\begin{array}{l}\text { Helps to restore } \\
\text { and protect the } \\
\text { natural } \\
\text { environment }\end{array}$ & $\begin{array}{l}\text { Retention and } \\
\text { corporate } \\
\text { relocation }\end{array}$ & $\begin{array}{l}\text { Can be a means of } \\
\text { education }\end{array}$ \\
\hline $\begin{array}{l}\text { Enhance } \\
\text { environment } \\
\text { quality }\end{array}$ & $\begin{array}{l}\text { Induce positive } \\
\text { publicity for } \\
\text { business }\end{array}$ & $\begin{array}{l}\text { Enable a better } \\
\text { appreciation and } \\
\text { awareness of nature } \\
\text { and the } \\
\text { environment }\end{array}$ \\
\hline $\begin{array}{l}\text { Support local plant } \\
\text { and } \\
\text { community }\end{array}$ & $\begin{array}{l}\text { Enhance the } \\
\text { facilities for } \\
\text { employees }\end{array}$ & $\begin{array}{l}\text { Provide } \\
\text { alternative transport } \\
\text { route }\end{array}$ \\
\hline $\begin{array}{l}\text { Provide wildlife } \\
\text { corridors }\end{array}$ & $\begin{array}{l}\text { Stimulate higher } \\
\text { productivity }\end{array}$ & $\begin{array}{l}\text { Democratize the } \\
\text { public mobility }\end{array}$ \\
\hline Support direct & Enhance wellbeing \\
\hline
\end{tabular}




\section{International Journal of Engineering Applied Sciences and Technology, 2021 \\ Vol. 6, Issue 2, ISSN No. 2455-2143, Pages 161-163 \\ Published Online June 2021 in IJEAST (http://www.ijeast.com)}

\begin{tabular}{|c|c|c|}
\hline biodiversity & $\begin{array}{l}\text { employment } \\
\text { opportunities }\end{array}$ & $\begin{array}{l}\text { through } \\
\text { with nature }\end{array}$ \\
\hline $\begin{array}{l}\text { Protect waterways } \\
\text { and } \\
\text { unpolluted }\end{array}$ & $\begin{array}{l}\text { Attract tourism } \\
\text { and enable } \\
\text { commercial } \\
\text { opportunities }\end{array}$ & $\begin{array}{l}\text { Provide visual } \\
\text { relief, especially in } \\
\text { urbanized areas }\end{array}$ \\
\hline $\begin{array}{l}\text { Help to reduce } \\
\text { flood hazard }\end{array}$ & $\begin{array}{l}\text { Improve the } \\
\text { overall appeal of } \\
\text { a community to } \\
\text { prospective new } \\
\text { residents }\end{array}$ & $\begin{array}{ll}\text { Induce } & \text { healthier } \\
\text { lifestyles } & \end{array}$ \\
\hline $\begin{array}{l}\text { Reduce problems } \\
\text { of soil erosion and } \\
\text { downstream } \\
\text { sedimentation }\end{array}$ & $\begin{array}{lr}\text { Increase } & \text { real- } \\
\text { estate } & \text { property } \\
\text { values } & \end{array}$ & $\begin{array}{l}\text { Provide access and } \\
\text { linkage between } \\
\text { natural and cultural } \\
\text { sites }\end{array}$ \\
\hline $\begin{array}{l}\text { Induce a more } \\
\text { efficient utilization } \\
\text { of land }\end{array}$ & $\begin{array}{l}\text { Helps to create } \\
\text { tax revenue and } \\
\text { reduce public } \\
\text { costs }\end{array}$ & $\begin{array}{l}\text { Help to preserve } \\
\text { monuments and } \\
\text { historical buildings }\end{array}$ \\
\hline \multirow[t]{4}{*}{$\begin{array}{ll}\text { Limit } & \text { urban } \\
\text { growth } & \end{array}$} & $\begin{array}{lr}\text { Cost effective } \\
\text { strategy for } \\
\text { providing } \\
\text { outdoor } \\
\text { recreation }\end{array}$ & $\begin{array}{l}\text { Enhance sense of } \\
\text { community }\end{array}$ \\
\hline & $\begin{array}{lr}\text { Reduce } & \text { car } \\
\text { related } & \text { family } \\
\text { budget } & \end{array}$ & $\begin{array}{l}\text { Anchor for } \\
\text { revitalizing } \\
\text { neighborhoods and } \\
\text { building healthy } \\
\text { communities }\end{array}$ \\
\hline & & $\begin{array}{lr}\begin{array}{l}\text { Facilitate } \\
\text { equity }\end{array} & \text { social } \\
\text { therefore, } & \text { and } \\
\text { cohesion } & \end{array}$ \\
\hline & & $\begin{array}{l}\text { Positive influence } \\
\text { on human behavior } \\
\text { and helps to reduce } \\
\text { crime }\end{array}$ \\
\hline
\end{tabular}

\section{CASE STUDIES AND ANALYSIS}

Urban greenways offer numerous benefits to the cities in which they are implemented, but much work goes into the creation of a greenway. Hundreds of greenway trails exist across the world presenting numerous urban greenway examples to study. How cities are planned, funded and implemented Greenways? To get an idea regarding the planning and implementation of Greenways, 3 case studies were studied. The planning processes, implementation, stakeholders involved, levels of coordination, and sources of funding for these three examples were studied.

Table -2 Case studies

\begin{tabular}{|l|r|r|r|l|}
\hline $\begin{array}{l}\text { S1 } \\
\text { No }\end{array}$ & Greenways & Location & Length & $\begin{array}{l}\text { Year } \\
\text { opened }\end{array}$ \\
\hline 1 & High Line & New York & $2.33 \mathrm{~km}$ & 2009 \\
\hline
\end{tabular}

\begin{tabular}{|l|l|l|l|l|}
\hline 2 & $\begin{array}{l}\text { Lambro river } \\
\text { valley }\end{array}$ & Italy & $17 \mathrm{~km}$ & 2000 \\
\hline 3 & $\begin{array}{l}\text { Multipurpose } \\
\text { greenway }\end{array}$ & Concord & $37 \mathrm{~km}$ & 2002 \\
\hline
\end{tabular}

\begin{tabular}{|c|c|c|c|}
\hline Category & High Line & $\begin{array}{l}\text { Lambro } \\
\text { river valley } \\
\text { Greenway }\end{array}$ & $\begin{array}{l}\text { Multipurpose } \\
\text { Greenway }\end{array}$ \\
\hline Place & New York & Italy & Concord \\
\hline $\begin{array}{l}\text { Type of } \\
\text { Greenway }\end{array}$ & $\begin{array}{l}\text { Recreational } \\
\text { greenway }\end{array}$ & $\begin{array}{l}\text { Urban river } \\
\text { side and } \\
\text { natural } \\
\text { corridor that } \\
\text { are of } \\
\text { ecological } \\
\text { importance. }\end{array}$ & $\begin{array}{l}\text { Multipurpose } \\
\text { greenway. }\end{array}$ \\
\hline $\begin{array}{l}\text { Before } \\
\text { Greenway }\end{array}$ & $\begin{array}{l}\text { Elevated } \\
\text { track for } \\
\text { goods } \\
\text { transport. } \\
\text { After } 1980 \\
\text { the structure } \\
\text { was } \\
\text { abandoned } \\
\text { and left to } \\
\text { rust and } \\
\text { became } \\
\text { grown over } \\
\text { with weeds. }\end{array}$ & $\begin{array}{l}\text { Polluted } \\
\text { Lambro } \\
\text { River due to } \\
\text { dumping of } \\
\text { waste. } \\
\text { Traffic } \\
\text { congestion. } \\
\text { Lack of } \\
\text { pedestrian } \\
\text { paths and } \\
\text { bicycle } \\
\text { paths }\end{array}$ & $\begin{array}{l}\text { Encroachmen } \\
\mathrm{t} \quad \text { and } \\
\text { booming } \\
\text { growth. } \\
\text { Riparian } \\
\text { corridors. } \\
\text { Polluted } \\
\text { Rocky River. }\end{array}$ \\
\hline $\begin{array}{l}\text { Purpose of } \\
\text { Greenway }\end{array}$ & $\begin{array}{l}\text { To preserve } \\
\text { the historic } \\
\text { structure. } \\
\text { To develop } \\
\text { public space } \\
\text { for people's } \\
\text { benefits. }\end{array}$ & $\begin{array}{l}\text { Protection } \\
\text { and } \\
\text { conservation } \\
\text { of Lambro } \\
\text { River. } \\
\text { Connect } \\
\text { people with } \\
\text { natural } \\
\text { resources } \\
\text { and centers } \\
\text { of life. }\end{array}$ & $\begin{array}{l}\text { Multipurpose } \\
\text { greenway } \\
\text { system to } \\
\text { tackle the } \\
\text { problems of } \\
\text { rapid growth } \\
\text { and } \\
\text { expansion. }\end{array}$ \\
\hline $\begin{array}{l}\text { Implementat } \\
\text { ion of } \\
\text { Greenway }\end{array}$ & $\begin{array}{l}\text { Public private } \\
\text { partnership } \\
\text { model }\end{array}$ & $\begin{array}{l}\text { Regional } \\
\text { level } \\
\text { Greenway } \\
\text { planning } \\
4 \text { phases }\end{array}$ & $\begin{array}{l}\text { Greenway } \\
\text { planning for } \\
\text { North } \\
\text { Carolina. } \\
\text { Broadly } 7 \\
\text { steps to be } \\
\text { followed }\end{array}$ \\
\hline $\begin{array}{l}\text { Community } \\
\text { participation }\end{array}$ & $\begin{array}{l}\text { Good } \\
\text { involvement } \\
\text { of people. }\end{array}$ & $\begin{array}{l}\text { Very less } \\
\text { involvement }\end{array}$ & $\begin{array}{l}\text { Equal } \\
\text { importance to } \\
\text { public }\end{array}$ \\
\hline Challenges & $\begin{array}{l}\text { Funding for } \\
\text { the } \\
\text { developments }\end{array}$ & $\begin{array}{l}\text { Unawarenes } \\
\text { s of people } \\
\text { regarding }\end{array}$ & $\begin{array}{l}\text { Unawareness } \\
\text { of people } \\
\text { regarding }\end{array}$ \\
\hline
\end{tabular}




\section{International Journal of Engineering Applied Sciences and Technology, 2021 \\ Vol. 6, Issue 2, ISSN No. 2455-2143, Pages 161-163 \\ Published Online June 2021 in IJEAST (http://www.ijeast.com)}

\begin{tabular}{|l|l|l|l|}
\hline & $\begin{array}{l}\text { Grass root } \\
\text { support. }\end{array}$ & $\begin{array}{l}\text { greenways. } \\
\text { Lack of } \\
\text { people's } \\
\text { participation } \\
\text { Densely } \\
\text { populated } \\
\text { areas }\end{array}$ & $\begin{array}{l}\text { Increased } \\
\text { urbanization } \\
\text { and } \\
\end{array}$ \\
& expansion. \\
\hline
\end{tabular}

\section{RECOMMENDATIONS FOR PLANNING}

The Greenway Plan can be developed through extensive outreach and dialogue with a wide range of interested stakeholders, including local public officials, local institutions, adjacent property owners, and the general public. The entire planning process can be organized in to 4 components:

-Background - What is the Plan? Overall project goals, objectives and context.

-Existing Resources - What do we have? Description of the area and its social and physical characteristics, as well as existing parks, recreation, cultural, and natural resources

-Recommendations - What do we want? Opportunities for local trail network and associated open spaces.

-Design Guidelines - What will it look like? Design description of typical trail types, including a survey of comparable trails in the local area. Idea regarding design components.

-Implementation Plan - How do we get it? Action plan to outline a realistic approach to implement the recommendations, including costs, timeline, and responsible parties.

\section{Factors to be considered for Greenway}

To develop a greenway certain factors to be considered. All these factors together will form a Greenway

- Understanding of natural resources within the area

- Understanding of centers of life

- Analysis of all routes and networks within the area

- Connect nearby open space facilities to form recreational activities

- Link recreation areas with residential, commercial, and cultural destinations

- Reserve existing open space for future recreation areas and to conserve natural resources

- $\quad$ Proper planning and implementation

1. Sustainable Design

To be successful in the long term, a greenway must be designed to be physically, ecologically, and economically sustainable.

2. Aesthetic Value
When designing each greenway network, careful attention must be given to its "look and feel," so that is designed appropriately to its specific setting.

\section{Paved Trails}

The Greenways Plan proposes a combination of paved and unpaved trails, to allow for different types of uses and different types of sites. Paved surfaces can be recommended to be asphalt.

\section{Natural Surface Trails}

For trails located in a natural setting, or intended for use mostly by people on foot, an unpaved or "soft" trail surface is appropriate. An unpaved surface can be constructed at far lower cost than a paved trail.

\section{Amenities}

Amenities and features as parking, restrooms, tables and benches, trash receptacles, bike racks, lighting, welcome signage, maps and directional signs, drinking fountains, and vending machines, rent a shop for cycles etc.

\section{REFERENCE}

[1] Aylin Salici, Mustafa Kemal University, Architecture Faculty, Department of Landscape Architecture, Turkey

[2] Ahern, J., 1995. Greenways as a Planning Strategy. Landscape and Urban Planning. Volume:33, 131-155 p.

[3] Ahern, J., 2004. Greenways in the USA: Theory, Trends and Prospects (Jongman, R. and G., Pungetti). Ecological Networks and Greenways, Concept, Design, Implementation, Cambridge University Press, 34-55 p. ISBN 0521827760.

[4] Ashley Conine, 2004. Planning for multi - purpose greenways in concord, North Carolina, Landscape and Urban Planning 68, 271-287 p.

[5] Bischoff, A., 1995. Greenways as Vehicles For Expression. Landscape and Urban Planning. Volume: 33, 317-325 p.

[6] Fabos, G.J., 1995. Introduction and Overview: The Greenway Movement, Uses And Potentials of Greenways. Landscape and Urban Planning. Volume: 33, 1-13 p.

[7] Natalia Fumagalli, Claudia Colombo, Paolo Stefano Ferrario, Giulio Senes, Alessandro Toccolini, Department of Agricultural and Environmental Sciences, University of Milan, Italy, Journal of Agricultural Engineering 2013; volume XLIV:183

[8] Scudo, K., 2006. The Greenway of Pavia: Innovations in Italian Landscape Planning. Landscape and Urban Planning 76, 112-133 p.

[9] Searns, R.M., 1995. The Evolution of Greenways as an Adaptive Urban Landscape Form. Landscape and Urban Planning 33, 65-80 p.

[10] www.umass.edu/greenway, (accessed on 11/10/2017) 